Arabiyat : Jurnal Pendidikan Bahasa Arab dan Kebahasaaraban

Vol. 7 No. 1, June 2020, 78-97

P-ISSN: 2356-153X; E-ISSN: 2442-9473

doi: http://dx.doi.org/10.15408/a.v7i1.13174

\title{
MORPHO-PHONOLOGICAL OF LOANWORDS IN LAMPUNG LANGUAGE FROM ARABIC
}

\author{
Muhammad Afif Amrulloh ${ }^{1}$, Luluk Humairo ${ }^{2}$ \\ ${ }^{1}$ Universitas Islam Negeri Raden Intan Lampung, Indonesia \\ Jl. Letnan Kolonel H. Endro Suratmin, Kota Bandar Lampung, 35131, Indonesia \\ ${ }^{2}$ Institut Agama Islam Negeri Samarinda, Indonesia \\ Jl. H. A. M. Rifaddin, Kota Samarinda, Kalimantan Timur, 75251, Indonesia \\ CorrespondingE-mail:afif.amrulloh@radenintan.ac.id
}

\begin{abstract}
The purpose of this discussion is to find out the process of changing loanwords and the form or type of loanwords that occur. The research method used is a descriptive method. This methodology focuses more on the "what" of the research subject rather than the "why" of the research subject. Data collection used in this study is content analysis and library techniques from literature sources such as dictionaries. Data analysis used in this study is the translational equivalent method. The results of this study found that the loanwords on Lampung language from Arabic through morphophonological processes in the form of sound attenuation, sound reinforcement, sound relaxation, addition of sound, reduction of multiple consonants, dissimilation, and aferesis. Then, the types of loanwords produced by the Lampung language from Arabic Language are in the form of full absorption patterns, partial absorption and pronunciation adjusment. This study contributes to the wealth of linguistic studies, especially Arabic and Lampung language which are widely spoken by the local community.
\end{abstract}

Keywords: aferesis, consonants, dissimilation, sound, loanwords

\section{Introduction}

Arabic is known as the language of instruction in Islam and it is also used as the international language for communication. The role of Arabic contributes to the development of Arabic itself. For example, the development of Arabic in Indonesia is in line with the activities of any merchants from various countries (especially Arabia) while preaching to spread Islam in Indonesia, the spread of Islam is also done by teaching religion, such as teaching about Sharia using Arabic as an intermediary which is then translated into traditional languages. ${ }^{1}$ Hence, the use of language is

1 Thonthowi, "Linguistic Thoughts as The Basis of Arabic Learning Innovation", Al-Bayan: Jurnal Jurusan Pendidikan Bahasa Arab, Vol. 10, No. 2, 2018, 94. 
fundamental in building relations between nations, ${ }^{2}$ that has an impact on the spread of Arabic that is directly related to the native language.

Arabic is a language that has its own privileges compared to other languages in the world. It is known that Arabic is the language used in the Koran, but it is not necessarily only used by people from the Arabian Peninsula, however the language listed in the Koran was revealed based on the ability of all peopleinthe world. ${ }^{3}$ Lampung language is one of the regional languages spoken by native Lampung people as a communication tool. Because language has an important role in communication and social interaction among its speakers. ${ }^{4}$ So, the speakers are native, it is also called as native language. There are two dialects in Lampung language, there are dialects $\mathrm{A}$ (Api) and the dialect $\mathrm{O}(\mathrm{Nyo})$.

The influence of words from Arabic into Lampung language does not occur instantly and all of sudden, but it has the several stages of sound change that are adjusted to the sound that is owned by the native language or speaker. But this is as common as the absorption of Indonesian into foreign languages, so this process is evidence of language development. ${ }^{5}$ Arabic has its own characteristics both from the style of language, oral written, sitematic, and arbite, ${ }^{6}$ because Arabic and Indonesian language have the different principle, whether the aspect of composing words or the structure of the word itself. Even though each language has the different system, it does not rule out the possibility of relation among the languages and they influence each other. Language is a picture of social interaction and changes in civilization in society because language is a communication tool for humans.

Then the use of Morphophonology or morphophonemic in language studies will be different in the use of languages in the world, ${ }^{8}$ especially Arabic that is used in various countries. For example in Arabic, the double consonant in the structure of a word is often found. Double consonant can be interpreted as the same consonant which is placed in a sequence. Therefore, in loanwords usually omits one sound of two sounds so that it no longer becomes double sound. For example, the word سنة Arabic is absorbed by releasing a consonant on the word, and it becomes sunah. Thus,

2 Muhammad Afif Amrulloh, "Analisis Kontrastif Proses Morfofonologi Bahasa Jawa dan Bahasa Arab”, Arabiyatuna: Jurnal Bahasa Arab, Vol. 2, No. 2, 2018, 175.

${ }^{3}$ M Yusuf, "Pengaruh Kemampuan Berbahasa Arab terhadap Prestasi Belajar al-Qur'an Hadits pada Siswa", An-Nizom: Jurnal Penelitian Manajemen Pendidikan Islam, Vol. 2, No. 1, 2017, 107-114.

${ }^{4}$ Muflihana Dwi Faiqoh, "Pemerolehan Fonologi Bahasa Arab Anak Usia 12 Tahun di MTs Islam Ngruki Sukoharjo (Tinjauan Psikolinguistik)", Journal CMES: Program Studi Sastra Arab FIB UNS, Vol. 7, No. 1, 57-67. 226-245.

${ }^{5}$ Rina Devianty, "Bahasa Sebagai Cermin Kebudayaan", Jurnal Tarbiyah, Vol. 24, No. 2, 2017,

${ }^{6}$ Lailatul Zuhriyah, Ahmad Sholihuddin, \& Muhammad Thohir, "Proses Afiksasi Morfologi Ism (Nomina) dalam Bahasa Arab", Arabiyat: Jurnal Pendidikan Bahasa Arab dan Kebahasaaraban, Vol. 5, No. 2, 2018, 292-313.

${ }^{7}$ Muhandis Azzuhri, "Bahasa dan Kearifan Lokal: Harmonisasi Sosial Masyarakat Arab - Jawa di Kampung Arab”, Arabi : Journal of Arabic Studies, Vol. 1, No. 2, 2016, 90.

${ }^{8}$ Firdos Atta \& Sidra Rasheed, "Morphophonemic Variations in the Saraiki Language", International Journal of Linguistics, Literature and Translation, Vol. 2, No. 3, 2019, 177-82. 
the study of sound symbolism in brand names may focus either on a combination of phonemes and phonemes, or on letters.

Sound changes in absorption can include levels of words, phrases and sentences. Some forms or types of sound changes according to Terry Crowley in his book entitled An Introduction to Historical Linguistics are nine types, namely lenition, sound addition, metathesis, fusion, unpacking, vowel breaking, assimilation, dissimilation, and unusual sound changes (abnormal sound change). ${ }^{10}$

Lenition is also called sound attenuation. According to Kridalaksana that lenition is categorized as soft sounds which when articulated are not followed by strong or tense currents. ${ }^{11}$ For example, in the word إجازة in Arabic which is absorbed into ijâzah/ijasah (diploma). /z/ sound becomes sound attenuation or lenition to sound that doesn't sound /s/. Thus, it is clear that lenition is one type of sound change in the absorption of Indonesian from Arabic. Therefore, in absorption this is done by removing one sound from the same two sounds so that it no longer becomes double or double. For example the word سنة in Arabic is absorbed by releasing a consonant on the word so that it becomes sunah. The same consecutive consonants in one word are released so that they include the type of double consonant reduction. ${ }^{12}$

Some of the previous studies discussed the similar topics of this research, which included a research conducted by Firdaus with the title "Kata-kata Serapan Bahasa Aceh dari Bahasa Arab; Analisis Morfofonemis" ("Loanwords of the Acehnese from Arabic; Morphonemic Analysis"). The study discussed the process of changing spelling and changing meanings after the vocabulary of the Arabic language was absorbed into the Acehnese language. Based on the results of the analysis, it was found that there was a change in the spelling of the Acehnese loanwords which included dissimilation, metathesis, diphthongization, monophthalmisation, anaptixis of prosthesis, ephesis, paragogic, aheresis, syncope and apocopy. In addition, changes in meaning also occur, such as fixed meanings, narrowing meanings and expanding meanings.

The research conducted by Hadi et. al. entitled "Perubahan Fonologis Kata-kata Serapan dari Bahasa Arab dalam Bahasa Indonesia (Phonological Change of Loanwords from Arabic in Indonesian)"discussed about sound changes that occur in the absorption of Arabic words in Indonesian. Based on the discussion, it was found that there were some sound changes that were not found in the absorption of Arabic words in Indonesian, namely haplology, consonant group reduction, prosthesis and

9 Åsa Abelin, "Phonaesthemes and Sound Symbolism in Swedish Brand Names", Ampersand, Vol. 2, 2015, 19-29.

10 Terry Crowley, An Introduction to Historical Linguistics, (Post Moresby: University of Papua New Guinea Press, 1987).

${ }^{11}$ Kridalaksana, Kamus Linguistik, (Jakarta: Gramedia, 1993).

12 Syamsul Hadi, Siti Chamamah Soeratno, M.Ramlan, \& I Dewa Putu Wijana, "Perubahan Fonologis Kata-Kata Serapan dari Bahasa Arab dalam Bahasa Indonesia”, Humaniora, Vol. 15, No. 2, 2003. 
abnormal sound changes. In addition, other changes in the form of monoftongization and abbreviations were also found. ${ }^{13}$

Another previous research is a research with the title "Perubahan Fonologis Katakata Serapan Bahasa Sunda dari Bahasa Arab; Studi Kasus pada Masyarakat Sunda di Jawa Barat, Indonesia" (Phonological Changes in the Loanwords of Sundanese from Arabic; Case Study of Sundanese Communities in West Java, Indonesia)" written by Ahmad Suherman. In this study, Sundanese was written in a Latin alphabet and was very phonetic. Phonological changes in Arabic language in the Sundanese language are transliteration of several hijaiyah letters such as 'ain, tha, shad and so on. ${ }^{14}$

The research conducted by Rozanna et al entitled "Languages in Contact: A Study of Arabic Loanwords in Malay/Indonesian Language" also discussed the similar topic. It was found that there are many Arabic words which are assimilated into Malay resulting from cultural and linguistic contacts, so there is a process of absorbing Arabic with Malay. In addition, the absorbing of language was occured due to the ease of reaching Southeast Asian countries where the majority of the population is Muslim. ${ }^{15}$

Moreover, a research with the title "Utilising Arabic-origin Loanwords in Teaching Malay as a Foreign Language" written by Kazuhito Uni resulted that the teaching loanwords also indicate the usefulness of the explicit presentation of etymologies for Malay words with meanings similar to those of the original Arabic words but slightly different phonetic forms, such as pakat ("agreement") from [muwâfaqa] ("agreement"), adat ("custom") from ["a:da] ("custom; habit"), seluar ("trousers") from [sirwâl] ("trousers") and iklan ("advertisement") from [illan] ("announcement; advertisement"), because the recognition of such similarities can promote faster vocabulary learning. ${ }^{16}$ Then the next type of sound change is the reduction of double consonants. In Arabic, the double sound placed in sequencein a word without a barrier is often found. Double consonant can be interpreted as the same consonant which is placed in a sequence. Therefore, in absorption this is done by removing one sound from the same two sounds so that it no longer becomes double or double. For example the word سنة in Arabic is absorbed by releasing a consonant on the word so that it becomes sunah. The same consecutive consonants in one word are released so that they include the type of double consonant reduction. ${ }^{17}$

This study discussed the morphological changes in phonological Arabic language words found in Lampung language. The purpose of this discussion is to find

13 Syamsul Hadi, Siti Chamamah Soeratno, M.Ramlan, \& I Dewa Putu Wijana, "Perubahan Fonologis Kata-Kata Serapan dari Bahasa Arab dalam Bahasa Indonesia”, 121.

${ }^{14}$ Suherman, "Perubahan Fonologis Kata-Kata Serapan Bahasa Sunda dari Bahasa Arab: Studi Kasus pada Masyarakat Sunda di Jawa Barat, Indonesia”, Sosiohumanika, Vol. 5, No. 1, 2012.

15 Rozanna Mulyani and Noordin Mohd Noor, "Languages in Contact: A Study of Arabic Loanwords in Malay/Indonesian Language", International Journal of Cultural and Art Studies, Vol. 1, No. 1, 2018, 36-40.

16 Kazuhito Uni, "Utilising Arabic-Origin Loanwords in Teaching Malay as a Foreign Language", Pertanika Journal of Social Science and Humanities, Vol. 23, No. 3, 2015, 665-80.

17 Syamsul Hadi, Siti Chamamah Soeratno, M.Ramlan, \& I Dewa Putu Wijana, "Perubahan Fonologis Kata-Kata Serapan dari Bahasa Arab dalam Bahasa Indonesia”, 121. 
out the process of changing loanwords and the form or type of loanwords that occur. The research method used is a descriptive method which is done by collecting, analyzing, and interpreting data. Descriptive research is defined as a research method that describes the characteristics of the population or phenomenon that is being studied. This methodology focuses more on the "what" of the research subject rather than the "why" of the research subject.

\section{Method}

The method used in conducting this research is a descriptive method. This descriptive method is done by collecting, analyzing, and interpreting the data. Data collection used content analysis and library techniques from literature sources such as dictionaries. The data analysis used the translational equivalent method, because this analysis involves two languages, Arabic and Lampung.

This method analyzed Loanwords in Lampung that the origin of the words is from Arabic.The research method used is a descriptive method which is done by collecting data, analyzing data and interpreting data. Descriptive research is defined as a research method that describes the characteristics of the population or phenomenon that is being studied. This methodology focuses more on the "what" of the research subject rather than the "why" of the research subject.

Data collection used in this study is content analysis and library techniques from literature sources such as dictionaries. Content analysis is a research technique for making replicable and valid inferences from texts (or other meaningful matter) to the contexts of their use. Data analysis used in this study is the translational equivalent method. Translational equivalence is the similarity between a word (or expression) in one language and its translation in another. Because this analysis involves two languages, they are Arabic and Lampung in phonological and morphological aspects. This method analyzed Loanwords in Lampung that their origin is from Arabic language.

\section{Result}

Phonological change is any sound change that alters the distribution of phonemes in a language. in addition to changes in language until its pronunciation is strongly influenced by elements of culture and tradition ${ }^{18}$. It is known that language is a composition of several consonants and vowels, Arabic consists of 28 consonants and three vowels. ${ }^{19}$

18 Reem Omar Maghrabi, "Variation and Variables in Some Arabic Varieties," Journal of Arts \& Humanities 08, no. 08 (2019): 17-39; Jerniati I, "Morfofonologi Dalam Konstruksi Nomina Bahasa Mandar: Perspektif Morfologi Generatif (Morphophonology in Noun Construction of Mandarese : Generative Morphology Perspective)", Jurnal Sawerigading, Vol. 23, No. 2, 2017.

19 Eftekhar Sadat Hashemi, Ferdows Aghagolzade, \& Arsalan Golfam, "Phonological Adaptation of Arabic Loan Words in Persian: Consonants Eftekhar Sadat Hashemi", International Journal of Humanities and Social Science, Vol. 4, No. 6, 2014, 225-36; al-Suwaiyan, Laila Abdullah. "Diglossia in the Arabic Language", International Journal of Language \& Linguistics, Vol. 5, No. 3, 2018. 
a. Lenition

Lenition is also called sound attenuation. According to Kridalaksana that lenition is categorized as soft sounds which when articulated are not followed by strong or tense currents. ${ }^{20}$

\begin{tabular}{|c|c|c|c|}
\hline Arabic Language & Transliteration & $\begin{array}{l}\text { The Loanwords in } \\
\text { lampung language }\end{array}$ & Meaning \\
\hline أمانة & Amânah & Amanat & Amanah (Trustful) \\
\hline جلّد & Jallada & Jilit & Jilid (Volume) \\
\hline 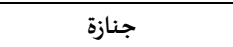 & Janâzah & Jenazah & Jenazah (Corpse) \\
\hline حقيقة & Haqîqah & Hakikat & Hakikat (Nature) \\
\hline قبلة & Qiblah & Kiblat & Kiblat (Qibla) \\
\hline مقبول & Maqbûl & Makbul & Makbul (Accepted) \\
\hline قدرة & Qudrah & Kodrat & Kodrat (Qodrat) \\
\hline فصيح & Fashîh & Paseh & Faseh (Fluent) \\
\hline مؤلف & Muallaf & Mualap & Mualaf (convert) \\
\hline زمان & Zamân & Jaman & Zaman (era) \\
\hline
\end{tabular}

This table showed the lenotion of several words of Arabic into Lampung language. For example, in the word إجازة An Arabic which is absorbed into ijâzah/ijasah (diploma). /z/ sound becomes sound attenuation or lenition to sound that doesn't sound /s/. The sound recitation is considered stronger than the sound that is not sounded (Darsita 2018). Thus, it is clear that lenition is one type of sound change in the absorption of Indonesian from Arabic.

\section{b. Sound reinforcement} sound.

Sound reinforcement is the change of sound from weak sound into a stronger

\begin{tabular}{cccc}
\hline Arabic Language & Transliteration & $\begin{array}{c}\text { The Loanwords in } \\
\text { lampung language }\end{array}$ & Meaning \\
\hline فajr & Fajak & Fajar (Dawn) \\
\hline فرف & Harf & Hukhup & Huruf (Letter) \\
\hline حسر & Jasad & Jasat & Jasad (Body) \\
\hline
\end{tabular}

It can be seen from the table that several of words are applying sound reinforcement. For example, in the word فجرin Arabic which is absorbed into pajakh (Dawn). / kh/ sound becomes sound reinforcement sound that doesn't sound /r/.

\section{c. Sound weakening (deletion)}

The processes of deletion and neutralization of sounds can be explained from morphological and morph syntactic perspectives which influence to rearrangement of the pronunciation and effects of phonologicalaspects. ${ }^{21}$

${ }^{20}$ Kridalaksana, Kamus Linguistik, (Jakarta: Gramedia, 1993). 
Arabiyât Jurnal Pendidikan Bahasa Arab dan Kebahasaaraban, 7 (1), 2020

\begin{tabular}{cccc}
\hline Arabic Language & Transliteration & $\begin{array}{c}\text { The Loanwords in } \\
\text { lampung language }\end{array}$ & Meaning \\
\hline Inshâf & Insap & Insaf (realize) \\
\hline مغرباف & Maghrib & manggekhip & Magrib (Dusk) \\
\hline Mubadzir & Mubazir & Mubazir (Redundant) \\
\hline مبذر & Astagfirullâh & Astaga & Astaghfirullah \\
\hline
\end{tabular}

This table showed the sound weakening of words. For example, in the word مبذرin Arabic which is absorbed into mubazir (redundant). /dz/ sound becomes sound weakening that doesn't sound /dz/, but it sounds /z/.

d. Sound addition

1) Epithesis

The vocal insertion / a/ between consonants /jl/ becoming "ajal", is a feature of the addition of sounds of the type of aphesis in the vowel /a/ in consonant groups. The word "Amn" has vocal / a/ insertion so it becomes "aman", it is a feature of the sounds addition of the type of aphesis in the vowel /a/ in consonants. The vowel insertion /a/ between consonants /jr/ and consonants/ $/$ / has a adjustment to the consonant /p/ and / r/ turns / kh/, so it becomes "pajakh", is a feature of the addition of sounds in type of apesesis to vowel /a/ in consonant clusters.

\begin{tabular}{cccc}
\hline Arabic Language & Transliteration & $\begin{array}{c}\text { The Loanwords in } \\
\text { lampung language }\end{array}$ & Meaning \\
\hline أجل & $A j l$ & Ajal & Ajal (Death) \\
\hline أمن & $A m n$ & Aman & Aman (Secure) \\
\hline فجر & Fajr & Pajakh & Fajar (Dawn) \\
\hline مجلس & Majlis & Majelis & Majlis (Majlis) \\
\hline
\end{tabular}

The table showed the ephitesis of words. For example, the vowel /e/ insertion also occurs in the word "majlis" between the consonant/jl/ so it becomes "majelis", is a feature of the addition of sounds of the type of aphesis to the vowel /e/ in consonant clusters.

\section{2) Paragog}

This term is generally applied to various kinds of vowel or consonant additions that are not true suffixes, but generally decorative additions meant to add emphasis, but that do not change the common meaning of the word. This is a general case especially in the development of acquisition of foreign languages called second languages, sometimes even having an impact on poor pronunciation. ${ }^{22}$

$\begin{array}{llll}\text { Arabic Language } & \text { Transliteration } & \text { The Loanwords in lampung } & \text { Meaning }\end{array}$

${ }^{21}$ Sami Hamdi, "Phonological Aspects of Jizani Arabic", International Journal of Language and Linguistics, Vol. 2, No. 6, 2015, 91-94.

${ }^{22}$ Nadia Bouchhioua, "Epenthesis in the Production of English Consonant Clusters by Tunisian EFL Learners", Applied Linguistics Research Journal, Vol. 3, No. 4, 2019, 33-44. 
Ara6iyât Jurnal Pendidikan Bahasa Arab dan Kebahasaaraban, 7 (1), 2020

\begin{tabular}{cccc}
\hline & \multicolumn{3}{c}{ language } \\
\hline Rizq & Rejeki & Rezeki (bounty) \\
\hline رزب & Qalb & Kalbu & Kalbu (Heart) \\
\hline علم & 'Ilm & Ilmu & Ilmu (Science) \\
\hline
\end{tabular}

This table showed the paragog of several words in Lampung language. For example, in the word علم ('ilm) in Arabic which is absorbed into ilmu (science). /'i/ sound becomes sound weakening that doesn't sound 'ilm, but it sounds ilmu.

e. Reduction of Double Consonants

Double (geminated) consonants were reduced to single ones.

\begin{tabular}{|c|c|c|c|}
\hline Arabic Language & Transliteration & $\begin{array}{l}\text { The Loanwords in } \\
\text { lampung language }\end{array}$ & Meaning \\
\hline حجّ & Hajj & Haji & Haji (Pilgrim) \\
\hline جنّ & Jinn & Jin & Jin (Genie) \\
\hline نبي & Nabiyy & $\mathrm{Nabi}$ & Nabi (Prophet) \\
\hline 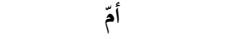 & Ummi & $U m i$ & Ibu (Mother) \\
\hline
\end{tabular}

The table showed the reduction of double consonants in Arabic words. For example, the word حج حaj) in Arabic is absorbed into haji (pilgrim). /jj/ in which the double consonant is disappeared, and it turns to "haji".

f. Dissimilation

Dissimilation is a phenomenon whereby similar consonants or vowels in a word become less similar.

\begin{tabular}{|c|c|c|c|}
\hline Arabic Language & Transliteration & $\begin{array}{l}\text { The Loanwords in } \\
\text { lampung language }\end{array}$ & Meaning \\
\hline دعاء & $D u^{\prime} \hat{a}$ & Dua & Doa (Praying) \\
\hline صحّة & Shihhah & Sihat & Sehat (Healthy) \\
\hline 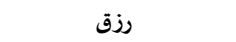 & Rizq & Rejeki & Rezeki (Bounty) \\
\hline
\end{tabular}

This table showed the dissimilation of words. The word " $d u$ ' $a$ " changes the phoneme $/ \varepsilon /$ in its original word to be a vowel phoneme / $/$, after being absorbed into Lampung the language, it changes to "Dua". Phoneme / $/$ /changes to /s/ because of the dissimilation. The changes of consonant $/ \mathrm{h} /$ also occur in the word "sibhah", after being loanword in Lampung, it becomes "sihat". The word "rizq" experiences the addition of phonemes / $/$ in the middle of the word and the vowel /i/ at the end of the word. In addition, the phoneme $/ \mathrm{z} / \mathrm{becomes} / \mathrm{j} /$ in the middle of the word so it becomes "rejeki" 


\section{g. Apheresis}

Apheresis (British English: aphaeresis) is the loss of one or more sounds from the beginning of a word, especially the loss of an unstressed vowel, thus producing a new form called an aphetism .

\begin{tabular}{cccc}
\hline Arabic Language & Transliteration & $\begin{array}{c}\text { The Loanwords in } \\
\text { lampung language }\end{array}$ & Meaning \\
\hline عبادة & Ibâdah & Ibadah & Ibadah (worship) \\
\hline عادل & 'Adil & Adil & Adil (fair) \\
\hline عادرات & 'Alim & Alim & Alim (Devout) \\
\hline ع & 'Aurat & Aurat & Aurat (Genital) \\
\hline
\end{tabular}

From the table above, it can be shown that the word of "ibadah" has a phoneme omission from / / or / $\varepsilon /$ becomes /i/. After being loanword, it becomes "ibadab". Phoneme /'/ or / $/$ / becoming /i/ occurs because of aferesis. The words "“ Adip', "'Alim", and "'aurat" which have /'/ or / $\varepsilon /$ changes into /a/. After Lampung loanwoard, the words turn into adil, alim and aurat. Phoneme /'/ or / $\varepsilon /$ becomes /a/ because of aferesis.

\section{The Form of Loanwords}

1. Consonant /b/ or / $/$

The consonant /b/ is a voiced consonant that is when the vocal cords vibrate when it is pronounced. Consonant / b/ produced by closing the lips is called a bilabial sound. In the example of "bala" and "baqa".

\begin{tabular}{|c|c|c|c|}
\hline Arabic Language & Transliteration & $\begin{array}{c}\text { Kata Serapan Bahasa } \\
\text { Lampung (The } \\
\text { Loanwords in } \\
\text { lampung language) }\end{array}$ & Makna (Meaning) \\
\hline بلاء & Balấ & Bala' & Bencana (Calamity) \\
\hline بقاء & Baqâ' & Baka & Baka (Eternal) \\
\hline قبلة & Qiblah & Kiblat & Kiblat (Qibla) \\
\hline كتاب & Kitâb & Kitab & Buku (Book) \\
\hline نبي & Nabiyy & Nabi & Nabi (Prophet) \\
\hline نصيب & Nasîb & Nasip & Nasib (Destiny) \\
\hline سبت & Sabt & Saptu & Sabtu (Saturday) \\
\hline 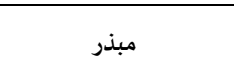 & Mubazir & Mubasir & $\begin{array}{l}\text { Berlebihan } \\
\text { (Wasteful) }\end{array}$ \\
\hline
\end{tabular}

It appears in the position of the consonant $/ \mathrm{b} /$ in the initial position there is no change, that is, it is precisely consonant $/ \mathrm{b} /$. It also occurs in the middle and final position as in the word qiblah, kitab, nabi, sabt, and mubazir. 


\section{Consonant $/ \mathrm{j} /$ or $/ \mathrm{e} /$}

The consonant $/ \mathrm{j} /$ is a voiced consonant that is when the vocal cords also vibrate when they are pronounced. Consonant $/ \mathrm{j} /$ is produced by pressing the tongue leaves on the hard palate called the pronto-platal.

\begin{tabular}{|c|c|c|c|}
\hline Arabic Language & Transliteration & $\begin{array}{l}\text { The Loanwords in } \\
\text { lampung language }\end{array}$ & Meaning \\
\hline جسد ا & Jasad & Jasat & Jasad (Body) \\
\hline 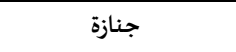 & Janâzah & Jenazah & Mayat (Corpse) \\
\hline جنَ & Jinn & Jin & Jin (Genie) \\
\hline حجّ & Hajj & Haji & Haji (Pilgrim) \\
\hline سجادة & Sajâdah & Sejadah & Sajadah (Prayer rug) \\
\hline سجود & Sujûd & Sujut & Sujud (Prostation) \\
\hline
\end{tabular}

It can be seen from the table that the consonant $/ \mathrm{j} /$ in the initial position as in the word "jasad", "janâzah" and "jimn" do not change, so do the middle and final positions such as sajâdah, haij and sujud.

\section{Consonant $/ \mathrm{kh} /$ or $/ \dot{\tau} /$}

The consonant $/ \mathrm{kh} /$ is a non-sounding consonant that is if the vocal cord does not vibrate when the sound is articulated.

\begin{tabular}{cccc}
\hline Arabic Language & Transliteration & $\begin{array}{c}\text { The Loanwords in } \\
\text { lampung language }\end{array}$ & Meaning \\
\hline إخلاص & Ikhlâsh & Ikhlas & Ikhlas (sincere) \\
\hline خصوص & Khusûsh & Khusus & Khusus (specific) \\
\hline اختيار & Ikhtiyâr & Ikhtiar & Ikhtiar (effort) \\
\hline اخلاق & Khilaf & Khilaf & Khilaf (errancy) \\
\hline اخلاق & Akhlâq & Akhlak & Etika (attitude) \\
\hline
\end{tabular}

From the table above, it is stated that the consonant $/ \mathrm{kh} /$ is produced by attaching the back of the tongue (active articulator) to the soft palate (passive articulator) called the dorso-velar. The consonant $/ \mathrm{kh} /$ at the initial position as in "khusus" and "khilâf" does not change, so does the middle position such as special kbusus, ikbtiyâr and akblâq.

\section{Consonant /s/ or/m/, / / / / /}

The consonant /s/ is a voiceless consonant. The consonant /s/ is produced by touching the tip of the tongue to the gum so that it causes narrowing of the exit of the air which then comes out slowly without an explosion called the alveolar.

\begin{tabular}{cccc}
\hline Arabic Language & Transliteration & $\begin{array}{c}\text { The Loanwords in } \\
\text { lampung language }\end{array}$ & Meaning \\
\hline سجود & Sujud & Sujut & Sujud (prostation) \\
\hline مدرسة & Madrasah & Madrasah & Madrasah (school) \\
\hline
\end{tabular}


Ara6iyât Jurnal Pendidikan Bahasa Arab dan Kebahasaaraban, 7 (1), 2020

\begin{tabular}{cccc}
\hline Masjid & Masjit & Masjid (mosque) \\
\hline Mustahîl & Mustahil & $\begin{array}{c}\text { Mustahil } \\
\text { (impossible) }\end{array}$ \\
\hline مستحيد & Sajâdah & Sejadah & $\begin{array}{c}\text { Sajadah (Prayer } \\
\text { Rug) }\end{array}$ \\
\hline Majlis & Majelis & Majlis (Majlis) \\
\hline
\end{tabular}

It can be seen from the table above that the consonant /s/ in the initial position as in "sujûd" and "sajâdah" does not change, as well as in the middle position "madrasab", "masjid", and "mustabîl", and at the final position like the "majlis".

\section{Consonant /f/ or / ف/}

The consonant /f/ is a voiceless consonant. The consonant /f/ is produced between the upper teeth and the lower lip pressed on the upper teeth so that there is a narrowing of the air because of that the air comes out shifting between the lips with the teeth and through the hole between the teeth called the labio dental.

\begin{tabular}{|c|c|c|c|}
\hline $\begin{array}{c}\text { Arabic } \\
\text { Language) }\end{array}$ & Transliteration) & $\begin{array}{l}\text { The Loanwords in } \\
\text { lampung language }\end{array}$ & Meaning \\
\hline فجر & Fajr & Fajakh & Fajar (Dawn) \\
\hline فهم & Fahm & Paham & Paham (Understand) \\
\hline فصيح & Fashîh & Paseh & Faseh (Fluent) \\
\hline حرف & Harf & Hukhuf & Huruf (Alphabet) \\
\hline
\end{tabular}

The table showed that the consonant / $\mathrm{f} /$ in the initial position as in the word fajar, fahm dan fasib does not change, so does the final position like the harf.

\section{Consonant $/ \mathrm{m} /$ or $/ \mathrm{p} /$}

The consonant $/ \mathrm{m} /$ or $/ \mathrm{p} /$ is a voiced consonant, which is if the vocal cords also vibrate when they are articulated. The consonant $/ \mathrm{m} /$ produced by closing the lips is called the bilabial.

\begin{tabular}{|c|c|c|c|}
\hline Arabic Language & Transliteration & $\begin{array}{l}\text { The Loanwords in } \\
\text { lampung language }\end{array}$ & Meaning) \\
\hline 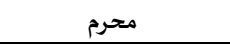 & Muhrim & Muhrim & Muhrim (Mahram) \\
\hline 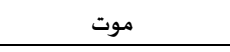 & Maut & Mati & Mati (Death) \\
\hline مقصود & Maqshûd & Maksud & Maksud (Meaning) \\
\hline 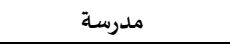 & Madrasah & Madrasah & Sekolah (School) \\
\hline 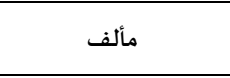 & Muallaf & Mualap & $\begin{array}{l}\text { Mualaf (Converted } \\
\text { muslim) }\end{array}$ \\
\hline مغرب & Maghrib & Maggekhip & Maghrib (Dusk) \\
\hline مقبول & Maqbûl & Makbul & Makbul (Fulfilled) \\
\hline مسكين & Miskîn & Miskin & Miskin (poor) \\
\hline
\end{tabular}

Based on this example, it can be seen that the consonant $/ \mathrm{m} /$ is maintained as a consonant $/ \mathrm{m} /$ in the initial position such as mubrim, maut, maqsîd, madrasah, muallaf, maggekhip, makbul, dan miskin. 


\section{Consonant $/ \mathrm{n} /$ or/ن/}

The consonant $/ \mathrm{n} /$ is a voiced consonant, which is if the vocal cords also vibrate when they are articulated. Consonant $/ \mathrm{n} /$ is produced with the tip of the tongue to the base of the tooth above the front of the gum called dental or interdental.

\begin{tabular}{cccc}
\hline Arabic Language & Transliteration & $\begin{array}{c}\text { The Loanwords in } \\
\text { lampung language }\end{array}$ & Meaning \\
\hline Syaithân & Sitan & Setan (Devil) \\
\hline شيطان & Nabiyy & Nabi & Nabi (Prophet) \\
\hline Inshâf & Insap & Insaf (realize) \\
\hline
\end{tabular}

In the example above, that the consonant / $\mathrm{n} /$ does not change, both in the initial position such as "nabi", in the middle position like "insap" and in the final position like "sitan".

\section{Consonant /h/ or / $/$ / / / /}

The consonant $/ \mathrm{h} /$ is a voiceless consonant that is if the vocal cords do not vibrate when the sound is articulated. Consonant / h/ produced by floating two vocal cords so that air from the lungs that pass between the roots of the tongue and the back wall of the esophagus is blocked, this process is called the sound of glotals.

\begin{tabular}{|c|c|c|c|}
\hline Arabic Language) & Transliteration & $\begin{array}{l}\text { The Loanwords in } \\
\text { lampung language }\end{array}$ & Meaning \\
\hline حاكم & Hâkim & Hakim & Hakim (Judge) \\
\hline حلال & Halâl & Halal & Halal (Legal) \\
\hline حاصل & Hâshil & Hasil & Hasil (Result) \\
\hline حكم & Hakm & Hukum & Hukum (Justice) \\
\hline الهام & Ilhâm & Ilham & Ilham (inspiration) \\
\hline جاهل & Jâhil & Jahil & Jahil (Abusive) \\
\hline صحّة & Sihhat & Sihat & Sehat (Healthy) \\
\hline
\end{tabular}

In the example above, it is clear that consonants / $\mathrm{h} /$ do not experience changes in both the initial position such as "hakim", "balal", "hasil", and "hakm", in the middle position like the word "ilham", "jabil" and "sibat".

9. Partial absorption pattern

Partial absorption is part of the phoneme contained in a word adjustment into the Indonesian language. This was done because in Indonesian the phoneme did not exist. This adjusment is usually in the form of phoneme removal or phoneme change.

\begin{tabular}{cccc}
\hline Arabic Language & Transliteration & $\begin{array}{c}\text { The Loanwords in } \\
\text { lampung language }\end{array}$ & Meaning \\
\hline عقل & Aql & Akal & Akal (Mind) \\
\hline عادل & Âdil & Adil & Adil (fair) \\
\hline عادبادة & 'Alim & Alim & Alim (devout) \\
\hline جماعة & 'Ibâdah & Ibadah & Ibadah (worship) \\
\hline & Jamâ'ah & Jema'ah & Jama'ah (congregation) \\
\hline
\end{tabular}


Ara6iyât Jurnal Pendidikan Bahasa Arab dan Kebahasaaraban, 7 (1), 2020

\begin{tabular}{cccc}
\hline & Shabr & Sabakh & Sabar (patient) \\
\hline Kursî & Fajr & Kersi & Kursi (chair) \\
\hline كرسي (dawn)
\end{tabular}

The table above showed the partial absorption pattern. For the example: "'aql”, “adil”, "alim”, “ibadab”, "jama'ab”, "Shabr”, "Kursi”, and "Fajr”. After being absorbed into Lampung, it becomes "akal”, "adil”, "alim", "ibadah", "jemaah", "sabakh", "kursi", and "pajakh". So, the words have phoneme omission.

10. Pattern of Adjustment

Consonant $/ \mathrm{h} /$ changes into / kh/ as in "fashîh". Besides that, it also changes consonant /f/ to /p/ after being Lampung loanword, it turns into "pasekh". The word "mualaf" in Arabic and absorbed into the Lampung language becomes "muallap". These changes occur in consonant phonemes /f/ become consonant phonemes $/ \mathrm{p} /$. The word "harf" has a change in the consonant / r/ to / kh/, and consonant /f/ to /p/. After being Lampung loanwords, it becomes "bukhup".

\begin{tabular}{cccc}
\hline Arabic Language & Transliteration & $\begin{array}{c}\text { The Loanwords in } \\
\text { lampung language }\end{array}$ & Meaning \\
\hline Fashîh & Pasekh & Fasih (Fluent) \\
\hline Muallaf & Muallap & $\begin{array}{c}\text { Mualaf (converted } \\
\text { muslim) }\end{array}$ \\
\hline Harf & Fajr & Hukhup & Huruf (Alphabet) \\
\hline حربح & Shabr & Pajakh & Fajar (Dawn) \\
\hline مبرف & Zamân & Sabakh & Sabar (Patient) \\
\hline مبذر & Mubadzir & Jaman & Zaman (Era) \\
\hline
\end{tabular}

From the example above, the phoneme changes also occur in Fajr and Shabr, which the change is in the consonant $/ \mathrm{r} /$ to $/ \mathrm{kh} /$, so it is absorbed into the Lampung language as pajakha nd sabakh. The changes of /z/ in the word "zamân" becomes "jaman" because the weakening of phonemes / $\mathrm{z} /$ into /j/. The word "Mubadrir", after being Lampung loanword, it becomes "mubazir". The phoneme change occurs, due to the $/ \mathrm{z} /$ lower phoneme in Lampung language.

\section{Discussion}

The Morphophonological Process of Loan Words in Lampung from Arabic, generally aims to make Arabic easier for non-Arabic speakers to understand Arabic both oral and written, as is the case with other foreign languages. ${ }^{23}$ Lenition is one form of sound change that occurs in absorption in linguistics in the form of phonemes that are weakly articulated, it means that the sounds which initially are strong or weakened become weak or soft sounds. Lenition is also called sound

${ }^{23}$ Laila Abdullah Al Suwaiyan, "Diglossia in the Arabic Language", International Journal of Language \& Linguistics, Vol. 5, No. 3, 2018, 228-38. 
attenuation. According to Kridalaksana that lenition is categorized as soft sounds which when articulated are not followed by strong or tense currents. ${ }^{24}$

Arabic is a language that has its own privileges compared to other languages in the world. It is known that Arabic is the language used in the Koran, but it is not necessarily only used by people from the Arabian Peninsula, however the language listed in the Koran was revealed based on the ability of all peoplein the world. ${ }^{25}$ The relation between two languages; Arabic and indigenous language, will result in a struggle between languages. Each language influences each other. This is in line with the nature of language that lives up to the times. One consequence of this twolanguage activity that is met is the emergence of language absorption, because the base form of language will produce a series of words. ${ }^{26}$

\section{Sound attenuation}

Sound changes in absorption can include levels of words, phrases and sentences. Some forms or types of sound changes according to Terry Crowley in his book entitled An Introduction to Historical Linguistics are nine types, namely lenition, sound addition, metathesis, fusion, unpacking, vowel breaking, assimilation, dissimilation, and unusual sound changes (abnormal sound change). ${ }^{27}$ Sound attenuation occurs in the words contained in the table above, as the word "amanab", the phoneme $/ \mathrm{h} /$ changes to $/ \mathrm{t} /$ and becomes "amanat". This is due to the phoneme /h/ higher than the consonant phoneme /t/. The word "Jallada" changes the consonant phoneme /d/ to /t/, in Lampung loanwords means "jilit". The word "Janâzah" has changed from a stronger sound change into a relatively lower sound, the change in the consonant phoneme /a/ becomes the consonant phoneme /e/, so, it changes into the Lampung language becoming "jenazah"

The word "Haqiqab" changes the phoneme of the consonant /q/ to /k/ becoming "bakikat". The word qiblah, the /h/ changes into /t/. So, qiblab in Arabic is absorbed into kiblat in Lampung loanwords. The word "Maqbûl", the consonant /q/ changes into $/ \mathrm{k} /$ and it becomes "makbul". The word "qudrab" changes the consonant phoneme $/ \mathrm{h} /$ to $/ \mathrm{t} /$. The weakening of the sound that occurs in the word "Fashîh" is processed when the /f/ sound changes to /p/ becoming "paseb". The word "Mualaf" the sound from the phoneme /f/ changes to /p/ so, it turns into Lampung loanword becoming "Mualap".

\section{Sound reinforcement}

The word "Fajr" experiences sound reinforcement because the phoneme /f/ in the word "fajr" is the original phoneme of Indonesian but it is a loanword and there is an addition of phonemes / $\mathrm{kh} /$ at the end of the word, so that it becomes "fajakb".

\footnotetext{
${ }^{24}$ Kridalaksana, Kamus Linguistik, (Jakarta: Gramedia, 1993).

${ }^{25}$ M Yusuf, "Pengaruh Kemampuan Berbahasa Arab terhadap Prestasi Belajar al-Qur'an Hadits pada Siswa”, An-Nizom: Jurnal Penelitian Manajemen Pendidikan Islam, Vol. 2, No. 1, 2017, 107-114.

${ }^{26}$ Mufrodi, "Fonologi dan Morfologi Bahasa Arab 'Amiyah Mesir", Arabiyat: Jurnal Pendidikan Bahasa Arab dan Kebahasaaraban, Vol. 2, No. 2, 2015, 192-215.

${ }^{27}$ Terry Crowley, An Introduction to Historical Linguistics, (Post Moresby: University of Papua New Guinea Press, 1987).
} 
Ara6iyât Jurnal Pendidikan Bahasa Arab dan Kebahasaaraban, 7 (1), 2020

The word "burf" becomes sound reinforcement and sound changes in phonemes / kh/ in the middle of the word. Sound reinforcement also occurs in the word "jasad".

\section{Sound loosening}

The phoneme /f/ in the word "inshaf" has a process of sound relaxation with phonetic features that change it into /p/ becoming "insap". The phoneme /p/ in Indonesian is a voiceless phoneme, while phoneme /f/ in Indonesian is a voiced phoneme. Phoneme $/ \mathrm{g} / \mathrm{has}$ a process of sound relaxation with phonetic features that change to / kh/ becoming "maggekhip". The word "maghrib" is supported by the phoneme /gh/ and there is the addition of consonants / $\mathrm{kh} /$ so it is absorbed into the Lampung language bceoming "maggekhip". So does the words mubardir and Astagfirullah.

4. Sound Addition

a) Epithesis

The vocal insertion /a/ between consonants /jl/ becoming "ajal", is a feature of the addition of sounds of the type of aphesis in the vowel /a/ in consonant groups. The word "Amn" has vocal /a/ insertion so it becomes "aman", it is a feature of the sounds addition of the type of aphesis in the vowel /a/ in consonants. The vowel insertion /a/ between consonants /jr/ and consonants/ $/$ / has a adjustment to the consonant /p/ and / r/ turns / kh/, so it becomes "pajakh", is a feature of the addition of sounds in type of apesesis to vowel /a/ in consonant clusters. The vowel /e/ insertion also occurs in the word "majlis" between the consonant /jl/ so it becomes "majelis", is a feature of the addition of sounds of the type of aphesis to the vowel /e/ in consonant clusters.

\section{b) Paragog}

The addition of sounds that occur in the "qalb" word into "kalbu" and phoneme $\mathrm{a}$ has a phoneme adjustment into / $/ \mathrm{k} /$ which is a type of paragog or an addition of vowel / $\mathrm{u} /$ after a word ends. "Rizq" word has the addition of sounds type paragog which is the addition of /i/ at the end of words, and phoneme arns into $/ \mathrm{k} /$, So, the sound changes into "rejeki". Then the word "ilm" becomes "ilmu" and phoneme $/ \varepsilon /$ has a adjustments into /i/, and vowel /i/ additionat the end of the word.

c) Reduction of Double Consonants

It is a release of one consonant in a double consonant, as in the words hajj, jinn, nabiyy, and ummi. In Arabic there are double consonants that are placed sequential in a word. After being a loanword in Lampung language, there is the omission of one of the double consonants. Then, it turns into a haji, jin, nabi and umi.

d) Dissimilation

The word " $d u$ ' $a a$ " changes the phoneme / $\varepsilon /$ in its original word to be a vowel phoneme /s/, after being absorbed into Lampung the language, it changes to "Du' $a$ ". 
Phoneme $/ \varepsilon /$ changes to $/ s /$ because of the dissimilation. The changes of consonant /h/ also occur in the word "sibhah", after being loanword in Lampung, it becomes "sibat". The word "rizq" experiences the addition of phonemes /o/ in the middle of the word and the vowel /i/ at the end of the word. In addition, the phoneme $/ \mathrm{z} /$ becomes $/ \mathrm{j} /$ in the middle of the word so it becomes "rejeki"

e) Aferesis

The word of "ibâdah" has a phoneme omission from /'/ or / $\varepsilon /$ becomes /i/. After being loanword, it becomes "ibadah”. Phoneme /'/ or / $/$ / becoming /i/ occurs because of aferesis. The words "'Adill, "' Alim", and "aurât" which have /'/ or / ع/ changes into $/ \mathrm{a} /$. After Lampung loanwoard, the words turn into adil, alim and aurat. Phoneme /'/ or / $\varepsilon /$ becomes /a/ because of aferesis.

\section{The Forms of Lampung Loanword from Arabic}

1. Full absorption pattern

Consonant / b / or / ب/

The consonant /b/ is a voiced consonant that is when the vocal cords vibrate when it is pronounced. Consonant /b/ produced by closing the lips is called a bilabial sound. In the example of "bala" and "baqâ", it appears in the position of the consonant /b/ in the initial position there is no change, that is, it is precisely consonant /b/. It also occurs in the middle and final position as in the word qiblab, kitâb, nabi, sabt, and mubazir.

\section{Consonant/j/ or / $/$}

The consonant $/ \mathrm{j} /$ is a voiced consonant that is when the vocal cords also vibrate when they are pronounced. Consonant $/ \mathrm{j} /$ is produced by pressing the tongue leaves on the hard palate called the pronto-platal. The consonant $/ \mathrm{j} / \mathrm{in}$ the initial position as in the word "jasd", "janâzah" and "jinn" do not change, so do the middle and final positions such as sajâdah, hajj and sujud.

\section{Consonant $/ \mathrm{kh} /$ or $/ \dot{\tau} /$}

The consonant $/ \mathrm{kh} /$ is a non-sounding consonant that is if the vocal cord does not vibrate when the sound is articulated. The consonant $/ \mathrm{kh} /$ is produced by attaching the back of the tongue (active articulator) to the soft palate (passive articulator) called the dorso-velar. The consonant $/ \mathrm{kh} /$ at the initial position as in "khusus" and "khilâf" does not change, so does the middle position such as special khusus, ikhtiyâr and akhlâq.

\section{Consonant /s/ or/w/, / / / / / /}

The consonant /s/ is a voiceless consonant. The consonant /s/ is produced by touching the tip of the tongue to the gum so that it causes narrowing of the exit of 
Ara6iyât Jurnal Pendidikan Bahasa Arab dan Kebahasaaraban, 7 (1), 2020

the air which then comes out slowly without an explosion called the alveolar. The consonant /s/ in the initial position as in "sujud" and "sajadah" does not change, as well as in the middle position "madrasah", "masjid", and "mustabil", and at the final position like the "majlis".

\section{/ف Consonant /f/ or}

The consonant /f/ is a voiceless consonant. The consonant /f/ is produced between the upper teeth and the lower lip pressed on the upper teeth so that there is a narrowing of the air because of that the air comes out shifting between the lips with the teeth and through the hole between the teeth called the labio dental. The consonant /f/ in the initial position as in the word fajar, fahm dan fasib does not change, so does the final position like the harf.

\section{Consonant $/ \mathrm{m} /$ or $/ \mathrm{\rho} /$}

The consonant $/ \mathrm{m} /$ or $/ \mathrm{p} /$ is a voiced consonant, which is if the vocal cords also vibrate when they are articulated. The consonant $/ \mathrm{m} /$ produced by closing the lips is called the bilabial. Based on this example, it can be seen that the consonant $/ \mathrm{m} /$ is maintained as a consonant $/ \mathrm{m} /$ in the initial position such as mubrim, maut, maqsud, madrasah, muallaf, maggekhip, makbul, dan miskin.

\section{Consonant /n/ or /ن/}

The consonant $/ \mathrm{n} /$ is a voiced consonant, which is if the vocal cords also vibrate when they are articulated. Consonant $/ \mathrm{n} /$ is produced with the tip of the tongue to the base of the tooth above the front of the gum called dental or interdental. In the example above, that the consonant $/ \mathrm{n} /$ does not change, both in the initial position such as "nabi", in the middle position like "insap" and in the final position like "sitan".

\section{Consonant / h / or / \& / / zl}

The consonant $/ \mathrm{h} /$ is a voiceless consonant that is if the vocal cords do not vibrate when the sound is articulated. Consonant $/ \mathrm{h} /$ produced by floating two vocal cords so that air from the lungs that pass between the roots of the tongue and the back wall of the esophagus is blocked, this process is called the sound of glotals. Consonants $/ \mathrm{h} /$ do not experience changes in both the initial position such as "bakim", "halal", "hasil", and "hakm", in the middle position like the word "ilham", "jabil" and "sibat".

\section{Partial absorption pattern}

Partial absorption is part of the phoneme contained in a word adjustment into the Indonesian language. This was done because in Indonesian the phoneme did not exist. This adjusment is usually in the form of phoneme removal or phoneme change. For the example: "aql”, "adil”, "alim”, "ibadab”, "jama'ab”, "shabr", "kursi”, and"Fajr". After being absorbed into Lampung, it becomes "akal", "adil”, "alim", "ibadab", "jemaah", "sabakh", "kursi", and "pajakh". So, the words have phoneme omission. 


\section{Recitation Adjustment Pattern}

Consonant $/ \mathrm{h} /$ changes into $/ \mathrm{kh} /$ as in "fasbii". Besides that, it also changes consonant /f/ to /p/ after being Lampung loanword, it turns into "pasekb". The word "mualaf" in Arabic and absorbed into the Lampung language becomes "muallap". These changes occur in consonant phonemes /f/ become consonant phonemes $/ \mathrm{p} /$. The word "harf" has a change in the consonant $/ \mathrm{r} /$ to $/ \mathrm{kh} /$, and consonant $/ \mathrm{f} /$ to $/ \mathrm{p} /$. After being Lampung loanwords, it becomes "bukbup". The phoneme changes also occur in fajr and shabr, which the change is in the consonant $/ \mathrm{r} /$ to $/ \mathrm{kh} /$, so it is absorbed into the Lampung language as pajakh and sabakh. The changes of $/ \mathrm{z} /$ in the word "zamân" becomes "jaman" because the weakening of phonemes $/ \mathrm{z} /$ into $/ \mathrm{j} /$. The word "mubadzir", after being Lampung loanword, it becomes "mubazir". The phoneme change occurs, due to the $/ z$ / lower phoneme in Lampung language.

\section{Conclusion}

Language phenomena cannot be separated from the development of language itself. Each language will have language upheaval due to the relation or interaction between languages. One of them is the problem of the emergence of loanwords in a language from another language. The phonological morphological theme of the Arabic loanwords found in Lampung. The purpose of this discussion is to find out the process of changing loanwords and the form or type of loanwords that occur. Then, the types of loanwords produced by the Lampung language from Arabic Language are in the form of full absorption patterns, partial absorption and pronunciation adjusment. It contributes to the wealth of linguistic studies, especially Arabic and Lampung language which are widely spoken by the local community. Therefore, in order to get a more in-depth study, further research about loanwords is expected, especially Lampung and Arabic.]

\section{REFERENCES}

Abelin, Åsa. "Phonaesthemes and Sound Symbolism in Swedish Brand Names", Ampersand, Vol. 2, 2015.

Amrulloh, Muhammad Afif. "Analisis Kontrastif Proses Morfofonologi Bahasa Jawa dan Bahasa Arab", Arabiyatuna : Jurnal Bahasa Arab, Vol. 2, No. 2, 2018.

Atta, Firdos., \& Sidra Rasheed. "Morphophonemic Variations in the Saraiki Language", International Journal of Linguistics, Literature and Translation, Vol. 2, No. 3, 2019.

Azzuhri, Muhandis. "Bahasa dan Kearifan Lokal: Harmonisasi Sosial Masyarakat Arab - Jawa Di Kampung Arab”, Arabi: Journal of Arabic Studies, Vol. 1, No. 2, 2016.

Bouchhioua, Nadia. "Epenthesis in the Production of English Consonant Clusters by Tunisian EFL Learners", Applied Linguistics Research Journal, Vol. 3, No. 4, 2019. 
Ara6iyât Jurnal Pendidikan Bahasa Arab dan Kebahasaaraban, 7 (1), 2020

Crowley, Terry. An Introduction to Historical Linguistics. Post Moresby: University of Papua New Guinea Press, 1987.

Devianty, Rina. "Bahasa Sebagai Cermin Kebudayaan”, Jurnal Tarbiyah, Vol. 24, No. 2, 2017.

Faiqoh, Muflihana Dwi. "Pemerolehan Fonologi Bahasa Arab Aanak Usia 12 Tahun di MTs Islam Ngruki Sukoharjo (Tinjauan Psikolinguistik)", Journal CMES: Program Studi Sastra Arab FIB UNS, Vol. 7, No. 1, 2014.

Hadi, Syamsul., Siti Chamamah Soeratno, M.Ramlan, \& I Dewa Putu Wijana. "Perubahan Fonologis Kata-Kata Serapan dari Bahasa Arab dalam Bahasa Indonesia", Humaniora, Vol. 15, No. 2, 2003.

Hamdi, Sami. "Phonological Aspects of Jizani Arabic", International Journal of Language and Linguistics, Vol. 2, No. 6, 2015.

Hashemi, Eftekhar Sadat., Ferdows Aghagolzade, \& Arsalan Golfam. "Phonological Adaptation of Arabic Loan Words in Persian: Consonants Eftekhar Sadat Hashemi", International Journal of Humanities and Social Science, Vol. 4, No. 6, 2014.

I, Jerniati. "Morfofonologi Dalam Konstruksi Nomina Bahasa Mandar: Perspektif Morfologi Generatif (Morphophonology in Noun Construction of Mandarese : Generative Morphology Perspective)", Jurnal Sawerigading, Vol. 23, No. 2, 2017.

Kridalaksana. Kamus Linguistik. Jakarta: Gramedia, 1993.

Maghrabi, Reem Omar. "Variation and Variables in Some Arabic Varieties", Journal of Arts \& Humanities, Vol. 8, No. 8, 2019.

Mufrodi. "Fonologi dan Morfologi Bahasa Arab 'Amiyah Mesir", Arabiyat: Jurnal Pendidikan Bahasa Arab dan Kebahasaaraban, Vol. 2, No. 2, 2015.

Mulyani, Rozanna., \& Noordin Mohd Noor. "Languages in Contact: A Study of Arabic Loanwords in Malay / Indonesian Language", International Journal of Cultural and Art Studies, Vol. 1, No. 1, 2018.

Suherman. "Perubahan Fonologis Kata-Kata Serapan Bahasa Sunda dari Bahasa Arab: Studi Kasus pada Masyarakat Sunda di Jawa Barat, Indonesia", Sosiobumanika, Vol. 5, No. 1, 2012.

al-Suwaiyan, Laila Abdullah. "Diglossia in the Arabic Language", International Journal of Language \& Linguistics, Vol. 5, No. 3, 2018.

Thonthowi. "Linguistic Thoughts as The Basis of Arabic Learning Innovation", Jurnal Al Bayan: Jurnal Jurusan Pendidikan Bahasa Arab, Vol. 10, No. 2, 2018.

Uni, Kazuhito. "Utilising Arabic-Origin Loanwords in Teaching Malay as a Foreign Language", Pertanika Journal of Social Science and Humanities, Vol. 23, No. 3, 2015. 
Ara6iyât Jurnal Pendidikan Bahasa Arab dan Kebahasaaraban, 7 (1), 2020

Yusuf, M. "Pengaruh Kemampuan Berbahasa Arab terhadap Prestasi Belajar al-Qur'an Hadits pada Siswa", An-Nizom: Jurnal Penelitian Manajemen Pendidikan Islam, Vol. 2, No. 1, 2017.

Zuhriyah, Lailatul., Ahmad Sholihuddin, \& Muhammad Thohir. "Proses Afiksasi Morfologi Ism (Nomina) Dalam Bahasa Arab", Arabiyat: Jurnal Pendidikan Bahasa Arab dan Kebahasaaraban, Vol. 5, No. 2, 2018. 